\title{
Is Criticism Disloyal? American Jews' Attitudes toward Israel ${ }^{\star}$
}

\section{Graham Wright $\mathbb{1}$, Leonard Saxe Brandeis University}

\section{Kenneth D. Wald (1) \\ University of Florida}

\begin{abstract}
To what extent is it possible for American Jews to maintain a deep emotional connection to Israel while criticizing the actions of the Israeli government? This long-debated question echoes earlier investigations of different forms of patriotism toward one's home country. Drawing on two 2019 surveys of American Jews, we find that, like Americans in general, Jewish liberals and conservatives express different forms of patriotism toward both Israel and America. Jewish conservatives tend to oppose criticism of Israel and America for any reason, while Jewish liberals view criticism as an important part of "caring" about both countries. Both forms of patriotism are positively associated with stronger emotional connections to the relevant country. These results suggest that emotional connection to Israel represents a form of social identification with Israel and that lower levels of connection to Israel among some American Jews are driven more by apathy than active criticism or hostility.
\end{abstract}

\section{INTRODUCTION}

President Trump once remarked that Jews who voted for Democrats were "being very disloyal to Jewish people, and ... being very disloyal to Israel" (Montanaro and Keith 2019). Although commentators noted that questioning Jews' national "loyalty" is a longstanding antisemitic trope

\footnotetext{
* The authors wish to thank Shahar Hecht for assistance with survey administration and helpful comments on the manuscript, Micha Rieser for data cleaning, and Deborah Grant and Ilana Friedman for editorial assistance. The paper also benefited from helpful comments from anonymous reviewers at Politics \& Religion. All errors remain our own.

Address correspondence and reprint requests to: Graham Wright, Brandeis University, 415 South Street, MS 014, Waltham, MA 02453-2728. E-mail: gwwri@brandeis.edu
} 
(Golinkin 2019), Trump's controversial remark highlights an apparent tension between American Jews' predominantly liberal political views and the increasingly conservative policies of Israeli governments. Scholars have long explored the implication of this tension for American Jewish attitudes to U.S. and Israeli politics (Oldmixon, Rosenson, and Wald 2005; Uslaner 2015; Waxman 2016), including whether it is leading American Jews to become less emotionally connected to Israel (Cohen and Kelman 2010; Barnett 2016). But what does it mean for American Jews to be "connected" to Israel, and to what extent does this connection imply particular political attitudes? How do American Jews manage to maintain a deep emotional connection to Israel while criticizing the actions of the Israeli government? These questions reflect broader debates about the extent to which a strong sense of connection between members of a diasporic community and their "homeland" leads to uncompromising, ethnocentric "long-distance nationalism."

In this paper, we show that research on the nature of patriotism and "national attachment" provides some answers. Echoing earlier findings of Americans in general (Huddy and Khatib 2007), we find that politically liberal and conservative Jews express their patriotism toward Israel and America in different ways. Conservative Jews tend to oppose criticism of Israel and the United States for any reason, while liberal Jews view criticism as an important part of "caring" about both Israel and America. Both forms of patriotism are positively associated with stronger emotional connections to the relevant country. In effect, emotional connection to Israel represents a form of social identification with Israel (Tajfel and Turner 1979; Theiss-Morse 2009). Consequently, lower levels of connection to Israel among some American Jews seem to be driven more by apathy than active criticism or hostility.

\section{"DISTANCING” FROM ISRAEL, AND “LONG-DISTANCE NATIONALISM" IN DIASPORA-HOMELAND RELATIONSHIPS}

In the past decade, the relationship between the United States and Israel has become increasingly intertwined with domestic U.S. politics (Rynhold 2015). Conflicts between the Obama and Netanyahu administrations over the Iran nuclear deal (Ross 2015), President Trump's decision to move the U.S. embassy to Jerusalem (Landler 2017), and disputes over the Boycotts, Divestment, and Sanctions (BDS) movement (Nelson 2016) point to a growing association between support for the Israel government 
and political conservatism in the United States. This political climate, and frustration over the repeated failure of Republican efforts to use the issue of Israel to win over large numbers of Jewish voters (Uslaner 2015), underlies President Trump's claim that Jewish Democrats are "disloyal."

Problematic as it is in terms of its link to antisemitic charges of Jewish "dual loyalty" (Golinkin 2019), President Trump's quote highlights the awkward position that some American Jews find themselves confronting in regard to Israel. On one hand, American Jews strongly identify as liberals aligned with the Democratic Party. This tendency is striking because American Jews identify as liberal at far higher levels than would be expected based on their socio-economic status and religiosity; American Jews are not just liberal, but anomalously so (Wald 2019). On the other hand, favorable views of Israel are more common on the political right (Oldmixon, Rosenson, and Wald 2005; Gries 2015), and, since the late 1970s, right-wing parties such as Likud have dominated Israeli politics (Waxman 2016). Liberal American Jews who "support" Israel may therefore feel a tension between their views on Israel and their domestic political attitudes; or, perhaps they do not. It all depends on what "supporting Israel" means to American Jews. Does support require unquestioning "loyalty" to the current Israeli government, or can criticism of Israel itself be a form of support?

Debate over this question has been a perennial fixture of scholarship on the U.S. Jewish community. Current scholarship suggests that, notwithstanding controversy surrounding Israel's birth, American Jews' support for Israel in the years following the 1967 six-day war was unequivocal, bipartisan, and uncontroversial (Waxman 2016, 35-39). American Jewish criticism of Israel began to grow in the 1970s and 1980s, but this criticism was opposed by many American Jewish organizations who felt that public criticism by American Jews could weaken Israel's position and divide worldwide Jewry (Sasson 2014, 24-32). American Jewish criticism of Israel was more evident during the 1980s and 1990s, but it was not until the 2000s that scholars of American Jews began to express alarm at the evidence of declining levels of reported emotional "connection" or "attachment" to Israel among younger Jews (Cohen 2002). ${ }^{1}$ This observation led to an intense debate over whether and, if so, to what extent American Jews are "distancing" from Israel, and what factors are driving this trend (Cohen and Kelman 2010; Keysar 2010; Sasson, Kadushin, and Saxe 2010; Sasson et al. 2012; Rynhold 2015).

Echoing a concern made prominent by journalists (e.g., Beinart 2010), some have argued that "distancing" from Israel is driven by American 
Jews' liberal political views. Barnett (2016), for example, contends that tension between Jews' liberal values and the Israeli government's rightwing policies is fostering alienation of American Jews from Israel. Others (Wald 2015; Gordis 2019) make a slightly different argument, claiming that liberal American Jews are becoming more critical of Israel not because of what the Israeli government is doing, but because of what the Israeli state represents. That is, because Israel is an "ethnic democracy" which explicitly favors a particular ethnic group, it disturbs liberal American sensibilities.

Other scholars have been skeptical of the idea that there is a major rift between American Jews and Israel (Saxe and Boxer 2012). Waxman (2016) accepts that American Jews are no longer willing to support Israel "blindly" and are increasingly willing to criticize it openly. But he contends that this shift in attitude does not mean that American Jews have become more "distant" from Israel. Rather, in response to the changing political situation in Israel, the form of Jews' connection to Israel has shifted from unequivocal support to constructive criticism. Sasson (2014) likewise argues that American Jews have not abandoned their support for Israel, but merely changed how they express this support, shifting from an approach based on "mobilization" facilitated through centralized advocacy organizations and toward personal "engagement" that is more in line with their own political views. Criticism of Israel may represent a new way by which some American Jews express their support for Israel. After all, one seldom criticizes that to which one is indifferent.

There is some empirical support for the notion that American Jews' political attitudes toward Israel are changing. For many years, survey data suggested that there was no significant relationship between American Jews' political attitudes and their sense of emotional connection to Israel (Cohen and Kelman 2010; Sasson, Kadushin, and Saxe 2010). In recent years, this appears to have changed, and more recent survey data find that, although many liberal Jews are still highly connected to Israel, their average levels of connection are lower than their conservative peers (Waxman 2016, 132n; Shain et al. 2015, 25). Notwithstanding these and other data, scholarly debate over the issue of "distancing" among American Jews has continued (Barnett 2018; Waxman 2018; Bard 2019).

Although they are not always acknowledged, similar challenges hamper efforts to explain the relationship of other diaspora communities to their ethno-religious homeland. Much of the work in this area is rooted in Benedict Anderson's conception of "long-distance nationalism" (Anderson 1998; 1994; Demmers 2002), which argues that diaspora 
members' feelings of dislocation, and the fact that their distance insulates them from the consequences of their political beliefs, lead them to support extremist, uncompromising, and ethno-nationalist policies in their homeland. Anderson's framework has been deployed in numerous case studies to explain the nature of the diaspora-homeland relationship among Serbians in Britain (Pryke 2003), Sri Lankan Tamils in the UK (Jones 2012), and Hindus in the United States (Kurien 2004; Thobani 2019). It has even been used to characterize the American Jewish community's relationship with Israel, with Conversi (2012) arguing that long-distance nationalism leads American Jews to be less tolerant of criticism of Israel than their Israeli counterparts, although this claim is at odds with public opinion data (Pew Research Center 2017) and most of the scholarship discussed above.

There have been some efforts to move away from this approach, emphasizing the heterogeneity of diaspora communities and their potential to promote peace as well as conflict (Smith 2007; Baser and Swain 2008), and noting its apparent inapplicability to American Jews (Dieckhoff 2017). But even critics of "long-distance nationalism" have apparently had little success in developing a more robust alternative framework that could help explicate the dynamics of diaspora-homeland relationships. Furthermore, because research on diaspora attitudes is largely confined to case studies, there have been few, if any, attempts to use public opinion data to statistically investigate the extent to which homeland "nationalism" among members of diaspora communities is actually associated with particular political attitudes in a systematic way.

The unanswered question underlying both of these debates is: what does it mean for a member of a diaspora community to be "connected" or "attached" to their homeland? To what extent does a deep personal or emotional connection with a homeland imply a particular political stance vis-a-vis the homeland's government, or a political ideology more broadly? For American Jews in particular, does being "emotionally connected or 'attached' to Israel represent a concern for the welfare of the Israeli state, critical or uncritical support for the current Israeli government, or something else?" Recent work (Forster, Sheskin, and Wald 2020) suggests that emotional connection to Israel forms a part of Jewish social identity, but is this really the case, and if so how does it relate to political attitudes? Despite debate over the level of American Jews' connection to Israel, scholars of American Jews and other diasporas have yet to formulate a theoretical framework for what "connection" means, or empirically analyze the extent to which it is associated with 
particular attitudes toward the Israeli government or U.S. politics. Such an analysis can help elucidate the extent to which there is really a tension between Jews' views on Israel and broader political attitudes, as well as the nature of diaspora-homeland relationships more broadly.

\section{PATRIOTISM, NATIONAL IDENTITY, AND IDEOLOGY}

Debates over the political dynamics of "attachment" among diaspora members with an ethnic-religious homeland echo discourse among political scientists about the ideological content of "patriotism" and "attachment" among citizens toward their own country. Early studies of patriotism (Adorno et al. 1950) conceptualized it as entailing blind and uncritical support for one's home country and rejection of other nations as out-groups. Later work attempted to distinguish patriotism (as merely "attachment to one's country") from other forms of intergroup discrimination, such as nationalism and ethnocentrism (Kosterman and Feshbach 1989; Bar-Tal 1993).

As early as the 1960s, Bellah (1967) pointed out two divergent forms of national attachment in the United States, which Marty (1974) named "priestly" and "prophetic." Priestly attachment essentially deifies the nation and brooks no criticism of it, while the prophetic form emphasizes the value of criticism as a means of calling on America to follow its values. Consistent with this insight, scholars have begun to conceptualize patriotism as a multidimensional construct, distinguishing between "constructive" and "uncritical" (or "blind") patriotism (Schatz, Staub, and Lavine 1999; Spry and Hornsey 2007).

Uncritical patriotism reflects an unwillingness to criticize one's own country for any reason or to accept criticism of it by others and can be measured by attitudes such as "my country is virtually always right" or "people who do not wholeheartedly support my country should live elsewhere." Constructive patriotism, by contrast, is a view that caring about one's country involves an obligation to point out its failures in order to effect positive change. Constructive patriotism is reflected in beliefs such as "I express my love for my country by supporting efforts at positive change" and "I oppose some of my country's policies because I care about it and want to improve it."

Importantly, each of these forms of patriotism is associated with a particular ideological viewpoint: Conservatives are more likely to express uncritical patriotism, while liberals are more likely to express constructive 
patriotism and less likely to express uncritical patriotism (Huddy and Khatib 2007; Sahar 2008). ${ }^{2}$ This suggests that, although liberals and conservatives both express "patriotism" toward their country, they do so in different ways.

Aside from these dual conceptions of patriotism, an additional construct appears even more important in characterizing Americans' sense of "attachment" to their home country. This notion of "national identity" (Theiss-Morse 2009) grows out of social identity theory (Tajfel and Turner 1979), which argues that emotional and affective attachments to social groups are a central component of self-esteem and self-identity. National identity represents a form of personal identification with one's home country and is analogous to how one might identify with a sports team or ethnic identity. Although we socially identify with multiple groups simultaneously, the strength of identification is key. The stronger our identification with a particular group, the more our own sense of self-identity becomes enmeshed with the group (Branscombe et al. 1999; Stets and Burke 2000). Thus, those with higher levels of American national identity see "being an American" as a more important part of their overall self-identity, and will be more concerned over adhering to what they perceive to be the norms of "good citizenship."

Huddy and Khatib (2007) attempted to parse the relationship between these constructs with respect to American national attachment. They found that national identity is relatively nonideological; that is, it is not associated with either liberal or conservative self-identification, but it is positively associated with both uncritical and constructive patriotism. ${ }^{3}$ Thus, conservatives are no more likely to strongly "identify" as Americans compared to liberals (or vice versa), but those who express either uncritical or constructive patriotism are more likely to strongly identify with America. In addition, they find that Americans with a stronger sense of national identity pay more attention to politics, while those with higher levels of uncritical patriotism pay less attention to politics. Constructive patriotism, by contrast, was not significantly associated with political attention one way or the other.

This work provides a framework for understanding the different ways that individuals can relate to the country in which they are citizens. But research has yet to investigate the extent to which these dynamics also apply to the relationship between members of a diaspora and an ethnicreligious homeland where they do not currently reside, and which they may never even have visited, as is the case for many American Jews and Israel. The distinction between uncritical patriotism, constructive 
patriotism, and national identity articulated by this research may help to explicate the relationship between American Jews' sense of "attachment" to Israel, their support for (or criticism of) the Israeli government, and their own domestic political attitudes.

This framework suggests that Jews may express different forms of patriotism (uncritical or constructive) toward Israel, depending on their preexisting political views. Emotional "connection" to Israel, by contrast, may represent a sense of social identification with Israel as a nation, similar to national identification with America. Given previous research, these constructs, patriotism and national identity, should be distinct but correlated. In this scenario, both forms of patriotism toward Israel will be correlated with a stronger sense of emotional connection to Israel. Emotional connection to Israel will be positively associated with paying closer attention to Israeli politics; simultaneously, uncritical patriots will be less interested in political events in Israel. Finally, because a preference for constructive or unconstructive patriotism appears to be strongly related to political ideology, American Jews will express a preference for one form of patriotism or the other in general, regardless of which country they are discussing. That is, liberal American Jews will be more likely to express constructive patriotism (and less likely to express uncritical patriotism) toward Israel and the United States.

To better understand the relationship between political attitudes and American Jewish views toward Israel and the United States, the present study tests a series of hypotheses. For each hypothesis, we test whether the relationship found by previous work with regard to Americans' views of the United States is also evident with regard to American Jews' attitudes toward the United States and Israel. First, we hypothesize that liberal Jews will be more likely to express constructive patriotism toward both Israel and America, and that politically conservative Jews will be more likely to express uncritical patriotism toward both Israel and America. Second, we hypothesize that both forms of patriotism toward America will be positively associated with emotional connection to America, and that both forms of patriotism toward Israel will be positively associated with emotional connection to Israel. In line with the findings that national identity is not related to ideology after controlling for patriotism, we expect that there will be little or no correlation between political ideology and connection to Israel after controlling for both forms of patriotism toward Israel. ${ }^{4}$ Finally, we hypothesize that emotional connection to America and constructive American patriotism will be positively associated with attention to U.S. politics, while uncritical American 
patriotism will be negatively associated with following U.S. politics. We also hypothesize that the same relationships will hold, mutatis mutandis, with regard to Israel.

\section{DATA AND METHODS}

Data for these analyses come from a 2019 survey of American Jews who applied to the Birthright Israel program between 2001 and 2009. Birthright Israel provides free, 10-day trips to Israel for American Jews between the ages of 18 and $27 . .^{5}$ Since its launch in 1999, the program has sent hundreds of thousands of Jews to Israel, but every year, there are far more applicants than available slots, and so the population of Birthright applicants includes a substantial number of American Jews who did not participate in the program (Saxe and Chazan 2008). ${ }^{6}$ Although the program's applicants are not a random sample of the broader American Jewish population, they include a broad cross-section of American Jews, from those with strong connections to Jewish life who had already traveled to Israel, to those with virtually no previous attachment to Jewish religious or cultural institutions (Saxe et al. 2011). Although only young adults are eligible for the trip, the broad range of applicant cohorts included in this study, and the time that has passed since application, means that the study includes American Jews who are currently between 29 and 46 years old.

The original sample frame for this survey was drawn from all applicants to Birthright between 2001 and 2009. Because this survey is the sixth wave of a longitudinal study of this population that has been in operation since 2009, contact information for panel members has been updated continuously over the previous decade. The survey was conducted primarily online, although some respondents were interviewed by phone. Respondents were offered a $\$ 25$ Amazon.com gift card as a guaranteed incentive for completing the survey, and extensive efforts were made to track down respondents. These efforts led to 2,544 completed interviews, corresponding to an overall response rate of $46 \%$ (AAPOR RR2). To reduce the nonresponse bias, responses were weighted to demographic targets from the pool of all Birthright applicants. ${ }^{7}$ Weights are applied to all analyses reported, with the exception of exploratory factor analyses.

Respondents' emotional connection to Israel was measured using the question "to what extent do you feel a connection to Israel?" with answer options of "not at all," "a little," "somewhat," and "very much." 
Respondents were also asked an analogous question about whether they feel a connection to "America," which included the same answer options. Questions measuring uncritical and constructive patriotism toward Israel and America were adapted from Huddy and Khatib (2007). Table 1 shows the question wording for each item, and the construct it is assumed to measure. All items included answer options of "strongly disagree," "disagree," "somewhat disagree," "somewhat agree," "agree," and "strongly agree."

When all eight of these items are included in an exploratory factor analysis, they load on just two factors-with all four uncritical patriotism items loading on the first, and the four constructive patriotism questions loading on the second. ${ }^{8}$ This suggests that, as hypothesized, respondents who express uncritical patriotism toward Israel tend to also express uncritical patriotism toward the United States, and the same goes for constructive patriotism. Nevertheless, because our hypotheses require us to analyze Israel and U.S. patriotism separately, uncritical and constructive patriotism items for each country are averaged, to create four separate variables: U.S. uncritical patriotism, U.S. constructive patriotism, Israel uncritical patriotism, and Israel constructive patriotism. ${ }^{9}$

Attention to American politics was measured with a question asking, "how closely do you follow U.S. politics on TV, radio, newspapers, or the internet," with answer options ranging from "not at all," to "fairly closely." Because it is expected that respondents will have a much lower baseline level of attention to Israeli politics, this construct was

Table 1. Uncritical and constructive patriotism questions

\begin{tabular}{|c|c|c|}
\hline & America & Israel \\
\hline \multirow[t]{2}{*}{$\begin{array}{l}\text { Uncritical } \\
\text { patriotism }\end{array}$} & $\begin{array}{l}\text { "There is too much criticism of } \\
\text { the United States in the world, } \\
\text { and we as Americans should } \\
\text { not criticize it" }\end{array}$ & $\begin{array}{l}\text { "There is too much criticism of } \\
\text { Israel in the world, and we as } \\
\text { Jews should not criticize it" }\end{array}$ \\
\hline & $\begin{array}{l}\text { "The United States is virtually } \\
\text { always right" }\end{array}$ & "Israel is virtually always right" \\
\hline $\begin{array}{l}\text { Constructive } \\
\text { patriotism }\end{array}$ & $\begin{array}{l}\text { "I oppose some United States } \\
\text { policies because I care about } \\
\text { my country and want to } \\
\text { improve it" } \\
\text { "If I criticize the United States, I } \\
\text { do so because I love it" }\end{array}$ & $\begin{array}{l}\text { "I oppose some of the Israeli } \\
\text { government's policies because I } \\
\text { care about Israel and want to } \\
\text { improve it" } \\
\text { "If I criticize Israel, I do so because } \\
\text { I love it" }\end{array}$ \\
\hline
\end{tabular}

Answer options: strongly disagree, disagree, somewhat disagree, somewhat agree, agree, strongly agree. 
measured using a different question: "In the PAST MONTH, how often have you actively sought news about Israel?" with answer options ranging from "never" to "several times a day." To test our hypotheses, we used OLS and ordered logit models. All models included a number of control variables, including whether or not the respondent was raised as an Orthodox Jew, whether the respondent had exclusively Jewish parents, and whether the respondent participated in Birthright Israel. ${ }^{10}$

\section{REPLICATION STUDY}

In addition to the main study, a replication study was also conducted to address two possible threats to validity. The first of these concerned the limited age range of the sample, especially the lack of respondents under the age of 29 . The second threat to validity involved our decision to ask respondents whether they feel a "connection" to Israel. Other prominent surveys, including the Pew Research Center's A Portrait of Jewish Americans, instead asked respondents if they feel an "emotional attachment" to Israel (Pew Research Center 2013). Although it is often assumed that both questions measure the same underlying construct (e.g., Miller and Dashefsky 2010), this notion has not been verified empirically.

To address these challenges, and to enhance both construct and external validity, all of the questions discussed above were also asked of a separate sample of more recent Birthright Israel applicants, who applied to the program in the summer of 2018 and were between the ages of 19 and 34 at the time of data collection. ${ }^{11}$ To explore the impact of the alternative question wording, all respondents were asked both the extent to which they felt a connection to Israel and the extent to which they felt an "emotional attachment" to Israel (with identical answer options). One of these questions was asked near the beginning of the survey and the other was asked near the end, and the order was varied randomly.

This replication study allowed us to conduct the following sensitivity analyses to test the validity of the original results. First, all analyses described above were re-run on this new dataset of younger respondents using identical model specifications. Second, the correlation between responses to the "connection" and "attachment" to Israel questions was computed, to determine how closely responses to these two questions mirrored one another. Finally, all models that included "connection" to Israel as either an independent or dependent variable were re-run using 
"attachment" to Israel instead. Results of these sensitivity analyses are discussed in the "replication study results" section below.

\section{LIMITATIONS OF THE SAMPLE FRAME}

Notwithstanding the replication, our analysis is limited to Jews who applied to Birthright Israel between 2001 and 2018. As noted above, this population is not a representative sample of Jewish Americans in general. The earlier application cohorts (2001-2009) analyzed in the main study have significantly higher levels of baseline Jewish religious and communal engagement compared to the broader Jewish population (Saxe et al. 2017, 34). For the more recent 2018 cohort included in the replication, these differences are smaller or nonexistent, presumably due to the broader participation in the program during this period (Wright, Hecht, and Saxe 2019, 39). Because our interest is in relationships among variables rather than the estimation of incidence rates, the fact that particular types of Jews may be over or underrepresented among Birthright applicants is not necessarily a serious threat to validity. Rather, the more serious concern is whether individuals with salient characteristics are excluded from the sampling frame altogether (Mercer et al. 2017).

One potentially important excluded group is Jews over the age of 46 . Research suggests that these individuals are likely to have higher baseline levels of emotional connection to Israel, both because attachment to Israel increases over the life course (Sasson et al. 2012) and because older Jews may have stronger bonds with Holocaust survivors (Forster, Sheskin, and Wald 2020). The debate among scholars of American Jews on the question of "distancing" focuses on the attitudes of younger Jews, who are characterized as deviating (in some way or another) from the unconditional support for Israel displayed by previous generations (see e.g., Cohen and Kelman 2010; Keysar 2010; Sasson et al. 2012; Waxman 2017). Thus, although the sample does include the age group of greatest interest to the scholarly literature on American Jews, the exclusion of Jews over the age of 46 from this study may downwardly bias the estimates of the correlation between connection to Israel and "uncritical" patriotism toward Israel.

Of perhaps greater importance is that the study population may also exclude Jews who did not apply to Birthright Israel because of their negative views of Israel. The effect of this omission may, however, be limited, 
since the Birthright applicant pool still includes a substantial number of individuals who hold negative attitudes toward Israel. For example, in the replication study, $11 \%$ of respondents "strongly agreed" that Israel "is guilty of violating the human rights of the Palestinian people." These potential biases should be taken into account in assessing the generalizability of these studies to the broader population of American Jews.

\section{MAIN STUDY: RESULTS}

OLS models were used to test whether political views are correlated with different forms of patriotism toward the United States and Israel in the same way (Table 2). Models 1 and 2 in Table 2 show that, as predicted, politically moderate and conservative Jews are significantly more likely to feel uncritical patriotism toward the United States, and significantly less likely to feel constructive patriotism toward the United States, compared to liberal Jews. As expected, Jewish background and participation in Birthright Israel are relatively unrelated to either form of patriotism toward the United States. The exception is having at least one nonJewish parent, which is associated with higher levels of constructive patriotism and lower levels of uncritical patriotism.

Models 3 and 4 in Table 2 show that, as predicted, Jewish moderates and conservatives are more likely to express uncritical patriotism toward Israel and less likely to express constructive patriotism toward Israel, compared to Jewish liberals. As expected, control variables related to Jewish background and Birthright Israel appear more strongly related to patriotism toward Israel than patriotism toward America. Jews with at least one non-Jewish parent are significantly less likely to express either constructive or uncritical patriotism toward Israel. Likewise, being raised Orthodox or participating in Birthright Israel are both associated with higher levels of constructive patriotism toward Israel but not significantly related to uncritical patriotism.

We now test whether, as predicted, both uncritical and constructive patriotism with respect to the United States and Israel are positively associated with emotional connection to each country. Table 3 presents results from ordered logistic regression models of emotional connection to the United States and Israel as a function of uncritical and critical patriotism toward the country in question, political ideology, and other potential confounders. Model 1 shows that, as predicted, respondents with higher levels of uncritical or constructive patriotism tend to be more emotionally 
Table 2. OLS models of uncritical and constructive patriotism toward the United States and Israel

\begin{tabular}{|c|c|c|c|c|}
\hline & $\begin{array}{c}\text { Model 1 } \\
\text { Uncritical patriotism } \\
\text { toward United States }\end{array}$ & $\begin{array}{c}\text { Model 2 } \\
\text { Constructive patriotism } \\
\text { toward United States }\end{array}$ & $\begin{array}{c}\text { Model } 3 \\
\text { Uncritical patriotism } \\
\text { toward Israel }\end{array}$ & $\begin{array}{c}\text { Model } 4 \\
\text { Constructive patriotism } \\
\text { toward Israel }\end{array}$ \\
\hline Liberal & (reference category) & (reference category) & (reference category) & (reference category) \\
\hline Moderate & $0.086(12.27) * * *$ & $-0.43(-6.72)^{* * *}$ & $0.93(10.78) * * *$ & $-0.25(-3.41)^{* *}$ \\
\hline Conservative & $1.63(18.14)^{* * *}$ & $-0.58(-6.60)^{* * *}$ & $1.69(18.49)^{* * *}$ & $-0.42(-4.34) * * *$ \\
\hline Raised Orthodox & $0.11(0.82)$ & $0.04(0.42)$ & $0.16(1.26)$ & $0.47(4.31)^{* * *}$ \\
\hline $\begin{array}{l}\text { Had at least one non- } \\
\text { Jewish parent }\end{array}$ & $-0.13(-2.27)^{*}$ & $0.13(2.12)^{*}$ & $-0.37(-4.87)^{* * *}$ & $-0.20(-2.50)^{*}$ \\
\hline $\begin{array}{l}\text { Birthright Israel } \\
\text { participant }\end{array}$ & $-0.01(-0.14)$ & $0.01(0.17)$ & $0.07(1.19)$ & $0.27(4.66)^{* * *}$ \\
\hline Constant & $1.78(37.99)^{* * *}$ & $4.79(97.39)^{* * *}$ & $2.38(39.44)^{* * *}$ & $4.16(78.28)^{* * *}$ \\
\hline$R^{2}$ & 0.31 & 0.06 & 0.25 & 0.05 \\
\hline$N$ & 2,373 & 2,365 & 2,362 & 2,352 \\
\hline
\end{tabular}

Note: Models run on weighted data. $T$ values in parentheses.

$\dagger p<0.1, * p<0.05, * * p<0.01, * * * p<0.001$. 
Table 3. Ordered logit models of connection to United States and Israel

\begin{tabular}{|c|c|c|c|}
\hline & $\begin{array}{c}\text { Model } 1 \\
\text { Connection to } \\
\text { the United States }\end{array}$ & & $\begin{array}{c}\text { Model } 2 \\
\text { Connection to } \\
\text { Israel }\end{array}$ \\
\hline Liberal & (reference category) & Liberal & $\begin{array}{l}\text { (reference } \\
\text { category) }\end{array}$ \\
\hline Moderate & $0.42(2.57)^{*}$ & Moderate & $0.30(2.00)^{*}$ \\
\hline Conservative & $0.38(1.67) \dagger$ & Conservative & $0.95(4.45)^{* * *}$ \\
\hline $\begin{array}{l}\text { Uncritical patriotism } \\
\text { toward United } \\
\text { States }\end{array}$ & $0.45(5.82)^{* * *}$ & $\begin{array}{l}\text { Uncritical } \\
\text { patriotism toward } \\
\text { Israel }\end{array}$ & $0.65(12.69)^{* * *}$ \\
\hline $\begin{array}{l}\text { Constructive } \\
\text { patriotism toward } \\
\text { United States }\end{array}$ & $0.65(10.22)^{* * *}$ & $\begin{array}{l}\text { Constructive } \\
\text { patriotism toward } \\
\text { Israel }\end{array}$ & $0.83(14.21)^{* * *}$ \\
\hline Raised Orthodox & $-0.16(-0.62)$ & Raised Orthodox & $1.10(3.81)^{* * *}$ \\
\hline $\begin{array}{l}\text { Had at least one non- } \\
\text { Jewish parent }\end{array}$ & $-0.20(-1.48)$ & $\begin{array}{l}\text { Had at least one } \\
\text { non-Jewish } \\
\text { parent }\end{array}$ & $-0.55(-4.38) * * *$ \\
\hline $\begin{array}{l}\text { Birthright Israel } \\
\text { participant }\end{array}$ & $0.03(0.26)$ & $\begin{array}{l}\text { Birthright Israel } \\
\text { participant }\end{array}$ & $0.72(6.25)^{* * *}$ \\
\hline$N$ & 2,358 & $N$ & 2,335 \\
\hline
\end{tabular}

Note: Models run on weighted data. Ordered logit coefficients. $Z$ values in parentheses. $\dagger p<0.1, * p<0.05, * * p<0.01, * * * p<0.001$.

connected to America. As expected, measures of Jewish background and participation in Birthright Israel are not significantly related to emotional connection to the United States. We also see that, contrary to our expectations that connection to America is nonideological, moderates and conservatives appear more strongly connected to America than liberals, although the result for conservatives is only significant at the $90 \%$ level.

Model 2 shows a similar pattern with regard to connection to Israel. Respondents who have higher levels of uncritical or constructive patriotism toward Israel are more likely to be connected to Israel. Respondents who did not have two Jewish parents tend to have lower levels of connection to Israel, while those who were raised Orthodox tend to have higher levels, suggesting that Jewish experiences in childhood are strong predictors of Israel attitudes later in life. Those who participated in Birthright Israel tend to have higher levels of connection to Israel, a relationship that has been documented repeatedly in past work (Sasson et al. 2014; Shain et al. 2015; Saxe et al. 2019). We also see that Jewish moderates and conservatives appear more connected to Israel than Jewish liberals, even after accounting for patriotism, suggesting that connection to Israel 
$100 \%$

$80 \%$

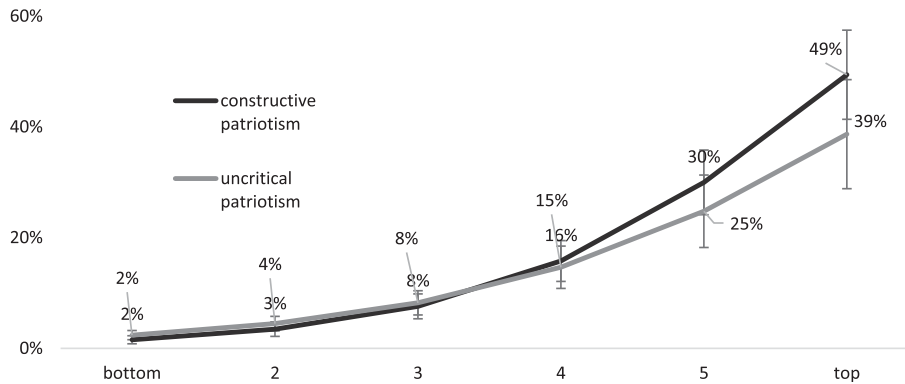

FIGURE 1. Predicted probability of being "very much" connected to Israel by uncritical and constructive patriotism

Note: Predicted margins and 95\% confidence intervals from Model 2 in Table 3. Uncritical/ constructive patriotism held at median value (3.5). Raised Orthodox held at 0 , having one nonJewish parent held at 0 , Birthright participation held at 0 , ideology held at "liberal."

does have some ideological content. Model 2 suggests that both ideology and patriotism have a significant impact on emotional connection to Israel. Unfortunately, coefficients from ordered logit models have no intuitive interpretation (Long 1997). Therefore, to provide an indication of the relative magnitude of these effects, Figures 1 and 2 present the predicted probability, derived from Model 2 in Table 3, that a respondent will be "very much" connected to Israel, for different levels of patriotism and ideology. Figure 1 shows the predicted probability of being very much connected to Israel as constructive patriotism increased (holding uncritical patriotism at 3.5 , the median value), and again as uncritical patriotism increases (holding constructive patriotism at 3.5, the median value). All predictions are for a respondent with exclusively Jewish parents, who was not raised Orthodox, did not participate in Birthright Israel, and who identifies as politically liberal. It can be seen that moving to higher levels of uncritical or constructive patriotism increases the likelihood of being "very much" connected from near zero to between $39 \%$ (for uncritical patriotism) and 49\% (for constructive patriotism).

Figure 2 presents probabilities for individuals with identical (viz. median) levels of uncritical and constructive patriotism, but who identify as liberal, moderate, and conservative. Thus, a liberal respondent with 


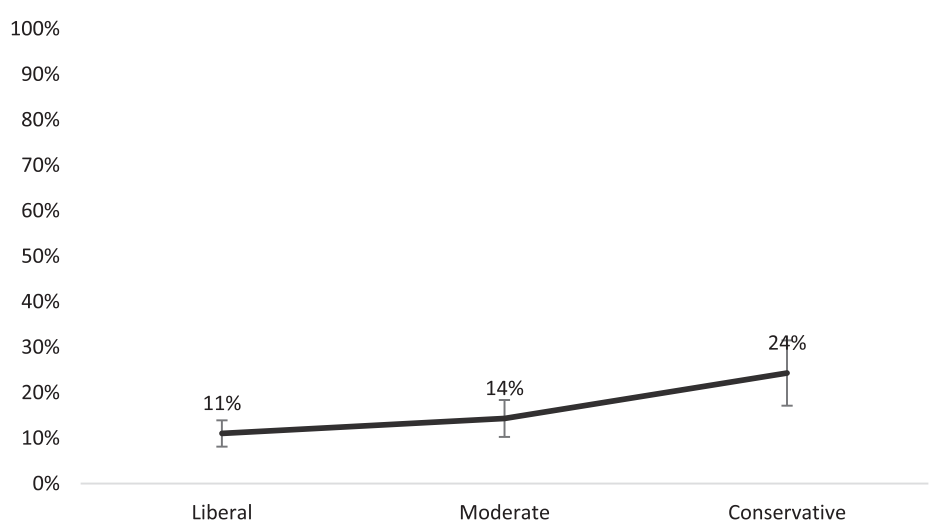

FIGURE 2. Predicted probability of being "very much" connected to Israel by political ideology

Note: Predicted margins and 95\% confidence intervals from Model 2 in Table 3. Uncritical and constructive patriotism both held at median value (3.5). Raised Orthodox held at 0 , having one non-Jewish parent held at 0 , Birthright participation held at 0 .

median levels of both constructive and uncritical patriotism toward Israel has an $11 \%$ probability of being "very much" connected to Israel. For a conservative respondent with identical levels of patriotism, the predicted probability is $24 \%$. These results illustrate two important points about the magnitude of the significant effects found in Model 2 above. First, although conservatives are substantially more likely to be strongly connected to Israel than liberals, there is relatively little difference between liberals and moderates in the likelihood of being "very much" connected to Israel. Second, patriotism of either type appears to be a far stronger predictor of connection to Israel than ideology.

Moving from attitudes to behaviors, we now explore whether emotional connection and patriotism are associated with political engagement of the form predicted by past work. Table 4 presents ordered logit models predicting how closely respondents follow U.S. and Israeli politics as a function of connection and patriotism to the country in question. Model 1 shows that individuals with stronger emotional connection to the United States, and those with higher levels of constructive patriotism, are significantly more likely to closely follow U.S. politics. Those with higher levels of uncritical U.S. patriotism, by contrast, are less likely to closely follow U.S. politics. Those who were raised Orthodox are less likely to follow U.S. politics closely, but having only one Jewish parent or participating in Birthright Israel are not significantly related to following U.S. politics. 
Table 4. Ordered logit models of following U.S. politics and checking news about Israel

\begin{tabular}{|c|c|c|c|}
\hline & $\begin{array}{c}\text { Model } 1 \\
\text { Following U.S. } \\
\text { politics }\end{array}$ & & $\begin{array}{c}\text { Model } 2 \\
\text { Checking news } \\
\text { about Israel }\end{array}$ \\
\hline Liberal & $\begin{array}{l}\text { (reference } \\
\text { category) }\end{array}$ & Liberal & $\begin{array}{l}\text { (reference } \\
\text { category) }\end{array}$ \\
\hline Moderate & $-0.72(-5.08) * * *$ & Moderate & $0.31(2.24)^{*}$ \\
\hline Conservative & $0.09(0.45)$ & Conservative & $1.11(5.94)^{* * *}$ \\
\hline $\begin{array}{l}\text { Connection to the } \\
\text { United States }\end{array}$ & $0.43(5.23) * * *$ & Connection to Israel & $0.77(10.89) * * *$ \\
\hline $\begin{array}{l}\text { Uncritical patriotism } \\
\text { toward United States }\end{array}$ & $-0.22(-3.53)^{* * *}$ & $\begin{array}{l}\text { Uncritical patriotism } \\
\text { toward Israel }\end{array}$ & $0.62(1.24)$ \\
\hline $\begin{array}{r}\text { Constructive patriotism } \\
\text { toward United States }\end{array}$ & $0.53(8.40)^{* * *}$ & $\begin{array}{l}\text { Constructive } \\
\text { patriotism toward } \\
\text { Israel }\end{array}$ & $0.31(4.97)^{* * *}$ \\
\hline Raised Orthodox & $-0.43(-2.38) *$ & Raised Orthodox & $0.31(1.42)$ \\
\hline $\begin{array}{l}\text { Had at least one non- } \\
\text { Jewish parent }\end{array}$ & $0.13(1.00)$ & $\begin{array}{l}\text { Had at least one non- } \\
\text { Jewish parent }\end{array}$ & $-0.04(-1.05)$ \\
\hline $\begin{array}{l}\text { Birthright Israel } \\
\text { participant }\end{array}$ & $0.03(0.25)$ & $\begin{array}{l}\text { Birthright Israel } \\
\text { participant }\end{array}$ & $-0.11(-1.05)$ \\
\hline$N$ & 2,349 & $N$ & 2,331 \\
\hline
\end{tabular}

Note: Models run on weighted data. Ordered logit coefficients. $Z$ values in parentheses. $\dagger p<0.1,{ }^{*} p<0.05, * * p<0.01, * * * p<0.001$.

With regard to political ideology, political moderates are less likely to follow U.S. politics compared to political liberals, but there is no significant difference between liberals and conservatives. In Model 2, we see a similar, but not an identical story with regard to following news about Israel. As above, emotional connection to Israel and constructive patriotism toward Israel are both positively associated with following Israeli news. Uncritical Israeli patriotism, however, is not significantly related to following Israeli news, nor are any of the control variables. Both conservatives and liberals are more likely to follow news about Israel compared to moderates.

\section{RESULTS OF REPLICATION STUDY}

The results of the replication study (presented in Tables A3-A6 in the Supplementary Appendix) were substantively identical to those reported above. As in the main study, an exploratory factor analysis found that the uncritical and constructive patriotism items loaded on the same two 
factors, regardless of which country they referred to. Similar to the results reported in Table 2, the replicated study found that moderates and conservatives had significantly higher levels of uncritical patriotism toward both Israel and America, compared to liberals. Moderates and conservatives likewise had significantly lower levels of constructive patriotism toward both Israel and America, although the coefficient for conservatives was only significant at the $90 \%$ level for both countries. Similar to the results presented in Table 3, the replication study found that, with respect to both Israel and the United States, uncritical and constructive patriotism were positively associated with connection to the country in question. In these models, moderates and conservatives were significantly more likely to be connected to both the United States and Israel, further indicating that connection to these countries has an ideological dimension among U.S. Jews. With regard to following U.S. and Israeli politics, the results of the replication study were virtually identical to those presented in Table 4, in terms of the sign and significance of the key independent variables. Finally, the replication study strongly suggests that questions asking about "connection" and "attachment" to Israel are both measuring the same underlying construct. The correlation between these two variables was high (Pearson's $r=0.75$, Cronbach's $\alpha=0.85$ ), and the results reported above with respect to "connection" to Israel remained substantively identical when this variable was replaced with "attachment" to Israel. In particular, both forms of patriotism toward Israel were positively and significantly associated with increased "attachment" to Israel (as was being politically moderate or conservative, having two Jewish parents, being raised Orthodox, or participating in Birthright Israel), and higher levels of attachment to Israel were associated with more closely following news about Israel. ${ }^{12}$

\section{DISCUSSION}

The present results demonstrate that American Jews' attitudes toward Israel follow many of the same dynamics as Americans' attitudes toward the United States. Like other Americans, politically liberal Jews appear to have a predisposition toward constructive patriotism, whereby criticism of a country - be it the United States or Israel—is considered a marker of concern and care for the country's future. Politically conservative Jews, by contrast, are more likely to express uncritical patriotism toward the United States and Israel and see criticism of either country 
as incompatible with the idea of patriotism. Critically though, both of these forms of patriotism are positively associated with stronger emotional connection to the country in question. All else being equal, Jews who support constructive criticism of Israel are more emotionally connected to Israel than those who do not express such support.

Those who are constructive critics of Israel, as well as those who are more emotionally connected to Israel, are more likely to keep up with news about Israel, just as those who are more connected to the United States, or who express constructive patriotism toward the United States, are more likely to follow U.S. politics. In light of earlier work (Huddy and Khatib 2007; Theiss-Morse 2009), these results suggest that emotional connection to Israel is a form of social identification with Israel. American Jews' feelings of emotional connection or attachment to Israel are thus not inherently associated with any particular position regarding criticism of Israel or the Israeli government, but rather represent an internalized sense of belonging to a social community, viz. Israel. This, in turn, suggests that Jewish liberals are unlikely to see a profound "tension" between their emotional connection to Israel and their criticism of the Israeli government, any more than other liberals see a tension between their criticism of Republican presidential administrations and their social identity as Americans. National attachment to one's country of residence has been studied repeatedly (Huddy and Khatib 2007; Theiss-Morse 2009; Levendusky 2017). However, as far as we have been able to establish, this is the first quantitative evidence that individuals can also socially identify with a country that they do not currently live in, and may never even have visited.

Even after accounting for their levels of uncritical and constructive patriotism, and the intensity of their Jewish backgrounds, Jews who identify as liberal are less to likely feel connected to Israel. However, the magnitude of ideological differences in connection to Israel is rather small, and is dwarfed by the substantial effect of either constructive or uncritical patriotism. As shown in Figure 1, a Jewish liberal who, on average, answers "agree" to questions about constructive patriotism has a $25 \%$ probability of being "very much" connected to Israel, roughly the same as a political conservative with a median level of both forms of patriotism.

Critically for the debate over the "distancing hypothesis," these results suggest that low levels of connection to Israel are not primarily driven by criticism of Israel-be it criticism of Israel's actions, or its status as an "ethnic democracy." Rather, strong expressions of "constructive criticism" toward Israel are associated with higher connection to Israel. The respondents with the lowest levels of connection to Israel are those who do not 
express either constructive or uncritical patriotism toward Israel. We also find that participation in Birthright Israel is significantly associated with higher levels of constructive patriotism toward Israel, but not uncritical patriotism; and, independent of this relationship, Birthright participation is associated with higher levels of connection to Israel. This result echoes earlier findings that Birthright Israel does not foster uncritical "long-distance nationalism" toward Israel, but instead increases emotional connection to Israel without significantly affecting participants' political attitudes toward Israel (Sasson et al. 2014; Saxe et al. 2019). Together, these results support the position that increased emotional connection with Israel does not imply increased association with a particular form of patriotic attachment.

The present study supports Waxman's (2016) argument that criticism of Israel is, itself, a form of connection. At the same time, it also undermines the claim that the rise of a more "critical" view of Israel among American Jews was driven by socio-political forces directly related to Israel. In the analyses presented above, we find that liberal and conservative Americans have a preference for uncritical or constructive patriotism in general, regardless of whether the focus concerns the United States or Israel. More likely is that any increase in the acceptability of Jewish criticism toward Israel (and any corresponding decrease in uncritical Israel patriotism) is largely epiphenomenal of American Jews becoming more liberal (Wald 2019). At the same time, it is notoriously difficult to determine why someone does not care about something they do not care about. For many Jews, lack of connection to Israel may simply reflect a lack of interest in the country one way or the other. Alienation from Israel, when it exists, seems more likely to be driven by apathy than active criticism.

More broadly, these findings suggest that the pre-existing work on patriotism and national attachment can provide a framework for understanding how diaspora members relate to their homeland that goes beyond "longdistance nationalism." The sense of attachment or social identification that diaspora members feel to their homeland should not be seen as necessarily implying any particular political stance. Moreover, our finding that political ideology tended to shape how American Jews feel about criticism of both the United States and Israel suggests that the extent to which diaspora members express militant or ethnocentric "long-distance nationalism" may actually depend as much on their domestic political views as on their level of emotional "connection" to their homeland.

Although Jews have often been considered the "archetypal diaspora" (Armstrong 1976), the American Jewish community is distinct from other modern diasporic communities, such as Cuban Americans or 
Tamil Canadians, not least in regard to its level of integration into broader American society. But this study of American Jews still suggests opportunities for future work that explores whether similar dynamics are at play in other ethnic-religious diaspora communities. More broadly, it suggests that the robust research on how citizens conceptualize patriotism and national identity has thus far unappreciated utility for understanding how individuals relate to countries they are not citizens of.

\section{CONCLUSION}

The present results suggest a new way to think about American Jews' views about Israel, and the relationship between connection to a religious-ethnic homeland and other political attitudes. Depending on their ideological disposition, American Jews may express their "patriotism" toward Israel in different ways. For conservative Jews, patriotism toward Israel is likely to manifest itself in an aversion to criticism of Israel, but for many liberal Jews, criticism of Israel is a critical component of what it means to "care" about Israel. In either case however, this patriotism is associated with a stronger sense of social identification with Israel. Just as other Americans, including American Jews, see "being American" as a part of who they are, many American Jews also view Israel as in some way connected to their own sense of self-identity. For liberal Jews then, criticism of Israel does not represent "disloyalty" toward Israel any more than criticism of the United States represents disloyalty toward America for other liberal Americans. Given this finding, it seems likely that President Trump's controversial comment, despite its invocation of antisemitic stereotypes, merely reflects broader liberal and conservative disagreements over the nature of patriotism, and the extent to which it is possible to criticize a country, while remaining "connected" to it.

\section{SUPPLEMENTARY MATERIAL}

To view supplementary material for this article, please visit https://doi.org/ $10.1017 /$ S1755048320000693.

\section{FUNDING DISCLOSURE}

Funding for this research was provided by the Michael and Andrea Leven Family Foundation, the Andrea and Charles Bronfman Philanthropies, the 


\section{Steinhardt Foundation for Jewish Life, and Birthright Israel. All conclu- sions are solely those of the authors.}

\section{NOTES}

1. As discussed in the "Replication Study" section, some scholars refer to "connection" to Israel while others refer to "attachment," but these terms are usually assumed to measure the same underlying construct (Miller and Dashefsky 2010), which we refer to here as "emotional connection."

2. Schatz, Staub, and Lavine (1999) likewise found that uncritical patriotism was associated with political conservatism but, in contrast to other work, did not find an association between constructive patriotism and liberalism.

3. Theiss-Morse $(2009,49-51)$ mostly echoes this conclusion but finds that extreme liberals are less likely to express American national identity compared to political moderates.

4. This prediction is not phrased as a formal "hypothesis" because it involves the expectation of a null result, which would paradoxically become "easier" to achieve as sample size (and statistical power) declines.

5. In 2018, Birthright Israel expanded its eligibility to include people up to age 32 . This change did not affect the respondents to the present study but does affect respondents to the replication study discussed below.

6. It should be emphasized that, among Birthright applicants, participation in the program is not self-selected. Participants are chosen from among available applicants primarily on the basis of logistical considerations, including the date of application and the correspondence between the applicant's own schedule and the dates of trips with available slots. But because Birthright trips are run by a number of independent "trip organizers," there is considerable variability in the precise procedure by which participants are selected.

7. Demographic targets included age, gender, round of application, participation status, and Jewish denomination at the time of registration.

8. Rotated factor loadings are shown in Table A2 in the Supplementary Appendix.

9. Cronbach's $\alpha$ for each of these two-item scales are as follows: uncritical U.S. patriotism: 0.76; constructive U.S. patriotism: 0.58; uncritical Israel patriotism: 0.81; constructive Israel patriotism: 0.71 .

10. Descriptive statistics for control variables can be found in A1 in the Supplementary Appendix. Alternative models were run that also controlled for additional measures of Jewish background, including most intense form of formal Jewish education and an index of Jewish ritual practice during high school. Because different measures of Jewish background tend to be highly correlated with one another, including these measures increases the correlation among independent variables, but did not substantively impact the results with respect to the patriotism and connection variables.

11. This survey was also conducted online during the same time period as the main study, and includes data from 3,469 respondents. Because no guaranteed incentive was offered, the response rate was much lower: $10.2 \%$ (AAPOR RR2). As with the main study, weights were calculated to correct for nonresponse bias by adjusting to demographic targets in the Birthright applicant pool.

12. An additional set of models were also run (on both datasets) that included controls for age and gender. In virtually all cases, the substantive results with respect to patriotism, connection, and ideology remained unchanged. The one exception was the marginally significant relationship between conservative ideology and connection to the United States in the main study (Table 3, Model 1), which is no longer statistically significant at the $90 \%$ level when these controls were included. This coefficient was still significant at the $99 \%$ level in the replication study however, regardless of whether controls for age and gender were included.

\section{REFERENCES}

Adorno, Theador W., Else Frenkel-Brunswick, Daniel J. Levinson, and R. Nevitt Sanford. 1950. The Authoritarian Personality. New York, NY: Harper and Row.

Anderson, Benedict. 1994. "Exodus." Critical Inquiry 20 (2): 314-327. 
Anderson, Benedict. 1998. The Spectre of Comparisons: Nationalism, Southeast Asia, and the World. New York, NY: Verso.

Armstrong, John A. 1976. "Mobilized and Proletarian Diasporas." The American Political Science Review 70 (2): 393-408.

Bar-Tal, Daniel. 1993. "Patriotism as Fundamental Beliefs of Group Members." Politics and the Individual 3 (2): 45-62.

Bard, Mitchell. 2019. "American Jews and the International Arena (April 2017-July 2018): The Gap Between American and Israeli Jews Widens as the Gap Between Governments Narrows." In American Jewish Year Book 2018, eds. Arnold Dashefsky and Ira M. Sheskin. Cham, Switzerland: Springer, 215-249.

Barnett, Michael. 2016. The Star and the Stripes. Princeton, NJ: Princeton University Press.

Barnett, Michael. 2018. "Review: Trouble in the Tribe: The American Jewish Conflict over Israel." Perspectives on Politics 16 (2): 475-476.

Baser, Bahar, and Ashok Swain. 2008. "Diasporas as Peacemakers: Third Party Mediations in Homeland Conflicts." International Journal on World Peace 25 (3): 7-28.

Beinart, Peter. 2010. "The Failure of the American Jewish Establishment." The New York Review of Books.

Bellah, Robert N. 1967. "Civil Religion in America." Deadalus 96 (1): 1-21.

Branscombe, Nyla R., Naomi Ellemers, Russell Spears, and Bertjan Dooje. 1999. "The Context and Content of Social Identity Threat." In Social Identity: Context, Commitment, Content, eds. Naomi Ellemers, Russell Spears and Bertjan Dooje. Oxford, UK: Blackwell Science, 35-58.

Cohen, Steven M. 2002. "Relationships of American Jews with Israel: What We Know and What We Need to Know."." Contemporary Jewry 23 (1): 132-155.

Cohen, Steven M., and Ari Y. Kelman. 2010. "Thinking About Distancing from Israel." Contemporary Jewry 30 (2): 287-296.

Conversi, Daniele. 2012. "Irresponsible Radicalisation: Diasporas, Globalisation and Long-Distance Nationalism in the Digital Age." Journal of Ethnic and Migration Studies 38 (9): 1357-1379.

Demmers, Jolle. 2002. "Diaspora and Conflict: Locality, Long-Distance Nationalism, and Delocalisation of Conflict Dynamics." The Public 9 (1): 85-96.

Dieckhoff, Alain. 2017. "The Jewish Diaspora and Israel: Belonging at Distance?" Nations and Nationalism 23 (2): 271-288.

Forster, A. Diana, Ira M. Sheskin, and Kenneth D. Wald. 2020. "The Political Consequences of Trauma: Holocaust Exposure and Emotional Attachment to Israel among American Jews." Contemporary Jewry 40 (2):209-236..

Golinkin, Lev. 2019. "Op-Ed: Trump's Disloyalty Lie About Jews Echoes a Blood-Soaked Anti-Semitic Slur." LA Times, accessed 11/5/2019. https://www.latimes.com/opinion/ story/2019-08-21/donald-trump-israel-jews-disloyalty.

Gordis, Daniel. 2019. We Stand Divided: The Rift Between American Jews and Israel. New York, NY: Harper Collins Publishers.

Gries, Peter Hayes. 2015. "How Ideology Divides American Liberals and Conservatives over Israel." Political Science Quarterly 130 (1): 51-78.

Huddy, Leonie, and Nadia Khatib. 2007. "American Patriotism, National Identity, and Political Involvement." American Journal of Political Science 51 (1): 63-77.

Jones, Demelza. 2012. "Diaspora Identification and Long-Distance Nationalism among Tamil Migrants of Diverse State Origins in the UK." Ethnic and Racial Studies 37 (14): 2547-2563.

Keysar, Ariela. 2010. "Distancing from Israel: Evidence on Jews of No Religion." Contemporary Jewry 30 (2): 199-204. 
Kosterman, Rick, and Seymour Feshbach. 1989. "Toward a Measure of Patriotic and Nationalistic Attitudes." Political Psychology 10 (2): 257-274.

Kurien, Prema. 2004. "Multiculturalism, Immigrant Religion, and Diasporic Nationalism: The Development of an American Hinduism." Social Problems 51 (3): 362-385.

Landler, Mark. 2017. "Trump Recognizes Jerusalem as Israel's Capital and Orders U.S. Embassy to Move." The New York Times, accessed 11/5/2019. https://www.nytimes. com/2017/12/06/world/middleeast/trump-jerusalem-israel-capital.html.

Levendusky, Matthew. 2017. "Americans, Not Partisans: Can Priming American National Identity Reduce Affective Polarization?" Journal of Politics 80 (1): 59-70.

Long, J. Scott. 1997. Regression Models for Categorical and Limited Dependent Variables, Advanced Quantitative Techniques in the Social Sciences. Thousand Oaks, CA: SAGE Publications, Inc.

Marty, Martin E. 1974. "Two Kinds of Two Kinds of Civil Religion." In American Civil Religion, eds. Russell E. Richey and Donald G. Jones. New York, NY: Harper \& Row, 139-157.

Mercer, Andrew W., Frauke Kreuter, Scott Keeter, and Elizabeth A. Stuart. 2017. "Theory and Practice in Nonprobability Surveys: Parallels Between Causal Inference and Survey Inference." Public Opinion Quarterly 81 (Special Issue): 250-279.

Miller, Ron, and Arnold Dashefsky. 2010. "Brandeis v. Cohen et al.: The Distancing From Israel Debate." Contemporary Jewry 30(1):155-164.

Montanaro, Domenico, and Tamara Keith. 2019. “Trump's 'Disloyalty' Claim About Jewish Democrats Shows He Doesn't Get How They Vote.” National Public Radio, accessed 11/5/2019. https://www.npr.org/2019/08/22/753131249/trumps-disloyaltyclaim-about-jewish-democrats-shows-he-doesn-t-get-how-they-vot.

Nelson, Cary. 2016. Dreams Deferred: A Concise Guide to the Israeli-Palestinian Conflict and the Movement to Boycott Israel. Bloomington, IN: Indiana University Press.

Oldmixon, Elizabeth A., Beth Rosenson, and Kenneth D. Wald. 2005. "Conflict over Israel: The Role of Religion, Race, Party and Ideology in the U.S. House of Representatives, 1997-2002." Terrorism and Political Violence 17 (3): 407-426.

Pew Research Center. 2013. A Portrait of Jewish Americans: Findings from a Pew Research Center Survey of U.S. Jews. Washington, DC: Pew Research Center's Religion \& Public Life Project.

Pew Research Center. 2017. "American and Israeli Jews: Twin Portraits from Pew Research Center Surveys.” Pew Research Center, accessed 5/28/2020. https://www.pewforum.org/ essay/american-and-israeli-jews-twin-portraits-from-pew-research-center-surveys/.

Pryke, Sam. 2003. "British Serbs and Long Distance Nationalism." Ethnic and Racial Studies 26 (1): 152-172.

Ross, Dennis. 2015. Doomed to Succeed: The US-Israel Relationship from Truman to Obama. New York, NY: Farrar, Straus and Giroux.

Rynhold, Jonathan. 2015. The Arab-Israeli Conflict in American Political Culture. New York, NY: Cambridge University Press.

Sahar, Gail. 2008. "Patriotism, Attributions for the 9/11 Attacks, and Support for War: Then and Now." Basic and Applied Social Psychology 30 (1): 189-197.

Sasson, Theodore. 2014. The New American Zionism. New York, NY: New York University Press.

Sasson, Theodore, Charles Kadushin, and Leonard Saxe. 2010. "Trends in American Jewish Attachment to Israel: An Assessment of the 'Distancing' Hypothesis." Contemporary Jewry 30 (2): 297-319.

Sasson, Theodore, Benjamin Phillips, Graham Wright, Charles Kadushin, and Leonard Saxe. 2012. "Understanding Young Adult Attachment to Israel: Period, Lifecycle and Generational Dynamics." Contemporary Jewry 32 (1): 67-84. 
Sasson, Theodore, Michelle Shain, Shahar Hecht, Graham Wright, and Leonard Saxe. 2014. "Does Taglit-Birthright Israel Foster Long-Distance Nationalism?" Nationalism and Ethnic Politics 20 (4): 438-454.

Saxe, Leonard, and Matthew Boxer. 2012. "Loyalty and Love of Israel by Diasporan Jews." Israel Studies 17 (2): 92-101.

Saxe, Leonard, and Barry Chazan. 2008. Ten Days of Birthright Israel. Waltham, MA: Brandeis University Press.

Saxe, Leonard, Benjamin T. Phillips, Theodore Sasson, Shahar Hecht, Michelle Shain, Graham Wright, and Charles Kadushin. 2011. "Intermarriage: The Impact and Lessons of Taglit-Birthright Israel." Contemporary Jewry 31 (2): 151-172.

Saxe, Leonard, Michelle Shain, Graham Wright, and Shahar Hecht. 2019. Israel, Politics, and Birthright Israel: Findings from the Summer 2017 Cohort. Waltham, MA: Cohen Center for Modern Jewish Studies, Brandeis University.

Saxe, Leonard, Michelle Shain, Graham Wright, Shahar Hecht, and Theodore Sasson. 2017. Beyond 10 days: Parents, Gender, Marriage, and the Long-term Impact of Birthright Israel. Waltham, MA: Cohen Center for Modern Jewish Studies.

Schatz, Robert T., Ervin Staub, and Howard Lavine. 1999. "On the Varieties of National Attachment: Blind versus Constructive Patriotism.” Political Psychology 20 (1): 151174.

Shain, Michelle, Leonard Saxe, Shahar Hecht, Graham Wright, and Theodore Sasson. 2015. Discovering Israel at War: The Impact of Taglit-Birthright Israel in Summer 2014. Waltham, MA: Cohen Center for Modern Jewish Studies.

Smith, Hazel. 2007. "Diasporas in International Conflict." In Diasporas in Conflict: PeaceMakers or Peace-Wreckers?, eds. Hazel Smith and Paul Stares. New York, NY: United Nations University Press, 3-16.

Spry, Carmen, and Matthew Hornsey. 2007. "The Influence of Blind and Constructive Patriotism on Attitudes Toward Multiculturalism and Immigration." Australian Journal of Psychology 59 (3): 151-158.

Stets, Jan E., and Peter J. Burke. 2000. "Identity Theory and Social Identity Theory." Social Psychology Quarterly 63 (3): 224-237.

Tajfel, Henri, and John C. Turner. 1979. “An Integrative Theory of Intergroup Conflict.” In The Social Psychology of Intergroup Relations, eds. William G. Austin and Stephen Worchel. Monterey, CA: Brooks/Cole, 33-47.

Theiss-Morse, Elizabeth. 2009. Who Counts as an American? The Boundaries of National Identity. New York, NY: Cambridge University Press.

Thobani, Sitara. 2019. "Alt-Right with the Hindu-Right: Long-Distance Nationalism and the Perfection of Hindutva." Ethnic and Racial Studies 42 (5): 745-762.

Uslaner, Eric M. 2015. "What's the Matter with Palm Beach County?" Politics and Religion 8 (4): 699-717.

Wald, Kenneth D. 2015. "The Choosing People: Interpreting the Puzzling Politics of American Jewry." Politics and Religion 8 (1): 4-35.

Wald, Kenneth D. 2019. The Foundations of American Jewish Liberalism. New York, NY: Cambridge University Press.

Waxman, Dov. 2016. Trouble in the Tribe: The American Jewish Conflict over Israel. Princeton, NJ: Princeton University Press.

Waxman, Dov. 2017. "Young American Jews and Israel: Beyond Birthright and BDS." Israel Studies 22 (3): 177-199.

Waxman, Dov. 2018. "Response to Michael Barnett's Review of 'Trouble in the Tribe: The American Jewish Conflict over Israel'." Perspectives on Politics 16 (2): 476-477. 
Wright, Graham, Shahar Hecht, and Leonard Saxe. 2019. Birthright's Impact on Five Jewish Identity Groups: Findings from the Summer 2018 Cohort. Waltham, MA: Cohen Center for Modern Jewish Studies.

Graham Wright is a lecturer at the Heller School for Social Policy and Management and an associate research scientist at the Cohen Center for Modern Jewish Studies at Brandeis University.

Leonard Saxe is the Klutznick Professor of Contemporary Jewish Studies and directs the Cohen Center for Modern Jewish Studies at Brandeis University.

Kenneth D. Wald is Distinguished Professor Emeritus of political science and the Samuel R. "Bud" Shorstein Professor Emeritus of American Jewish Culture \& Society at the University of Florida, Gainesville. 